\title{
Virtual Learning of the Digestive System: An Experience Developing an Undergraduate Course
}

\author{
Rodolfo E. Avila ${ }^{1}$, Hugo Juri ${ }^{1}$, María E. Samar ${ }^{2}$, Maria T. Mugnaini ${ }^{3}$, \\ Carlos Soñez ${ }^{3}$, William Anderson ${ }^{4}$ \\ ${ }^{1}$ School of Medicine, National University of Córdoba, Córdoba, Argentina \\ ${ }^{2}$ School of Dentistry, National University of Córdoba, Córdoba, Argentina \\ ${ }^{3}$ College of Agriculture and Veterinary Medicine, National University of Río Cuarto, \\ Córdoba, Argentina \\ ${ }^{4}$ John Radcliffe Hospital, Oxford, UK \\ Email: w.anderson@doctors.org.uk
}

Received July $17^{\text {th }}$, 2013; revised August $17^{\text {th }}$, 2013; accepted August $25^{\text {th }}, 2013$

\begin{abstract}
Copyright (c) 2013 Rodolfo E. Avila et al. This is an open access article distributed under the Creative Commons Attribution License, which permits unrestricted use, distribution, and reproduction in any medium, provided the original work is properly cited.
\end{abstract}

\begin{abstract}
Using modern information and communication technology associated with distance education, we set out to produce an e-learning course to improve students' understanding of the digestive system in an interdisciplinary manner. To achieve this, we implemented a novel undergraduate teaching project in classes at the Faculties of Agricultural Sciences and Veterinary Medicine of the National University of Rio Cuarto, and Medical Sciences of the National University of Cordoba. In the context of other groups' experiences we report our development of an undergraduate e-learning course, covering embryology, histology and cell biology in an integrated thematic unit.
\end{abstract}

Keywords: Use of the Internet; Academic Integration Network; Virtual Teaching; Digestive System; E-Learning

\section{Introduction}

Cell biology, histology and embryology are three core subjects which are taught early in medicine, dentistry and veterinary science curricula. Collectively, they provide an essential foundation for the subsequent acquisition of clinical knowledge in each discipline; while conversely, an inability to assimilate such knowledge can lead to high failure and dropout rates in the early years of these degrees.

Teaching of these sciences has traditionally been delivered through classroom-based methods and can thus be limited by time and financial constraints. Increasingly, the availability of online resources and electronic learning or "e-learning", is greatly facilitating this learning process while circumventing the need for expensive laboratory equipment (Goldberg, 2007; Silva Lópes, 2003).

Using information and communication technology associated with distance education, we set out to produce an e-learning course dedicated to the digestive system, aiming to promote an integrated comprehension. To achieve this, we implemented an undergraduate teaching project at the faculties of Agricultural Sciences and Veterinary Medicine of the National University of Rio Cuarto and also within Medical Sciences of the National University of Cordoba.

In this communication we describe our experience of using the Internet in a network of academic integration: virtual teaching of the digestive system as an integrated thematic unit of embryology, histology and cell biology.

\section{Materials and Methodology}

The practical tasks "Virtual Oral Cavity and Digestive System" were prepared for the 2010 academic year and uploaded to the URL: http://www.histologiavirtual.com.ar/.

Those who took part as nodes were the Department of Cell Biology and General Embryology at the National University of Rio Cuarto, Argentina (Node 1) and at the National University of Cordoba, the departments of Cell Biology, Histology and Embryology (Node 2) and Medical Computing (Node 3). Images of organs within the digestive system of various species were obtained from departments participating in the network and used for the learning exercises (see Figures 1 and 2).

Image files have JPEG and GIF extensions. Digital images of histological cross-sections were obtained using an image analyzer with the "Image ProPlus" software connected to an Olympus Bx50 photomicroscope. Microsoft Office SharePoint Designer software was used as a designing and programming tool for the development of the website.

\section{Results}

The Virtual Practical Task "Oral Cavity" consisted of a main page of 28 thumbnail images. Individual thumbnails could be selected, in order to present the user with an additional screen displaying an enlarged and fully-labelled image, with accompanying text outlining the important structures. Similarly, the Virtual Practical Task "Digestive System" contained 32 thumbnail images on the screen, which could also be selected to dis- 


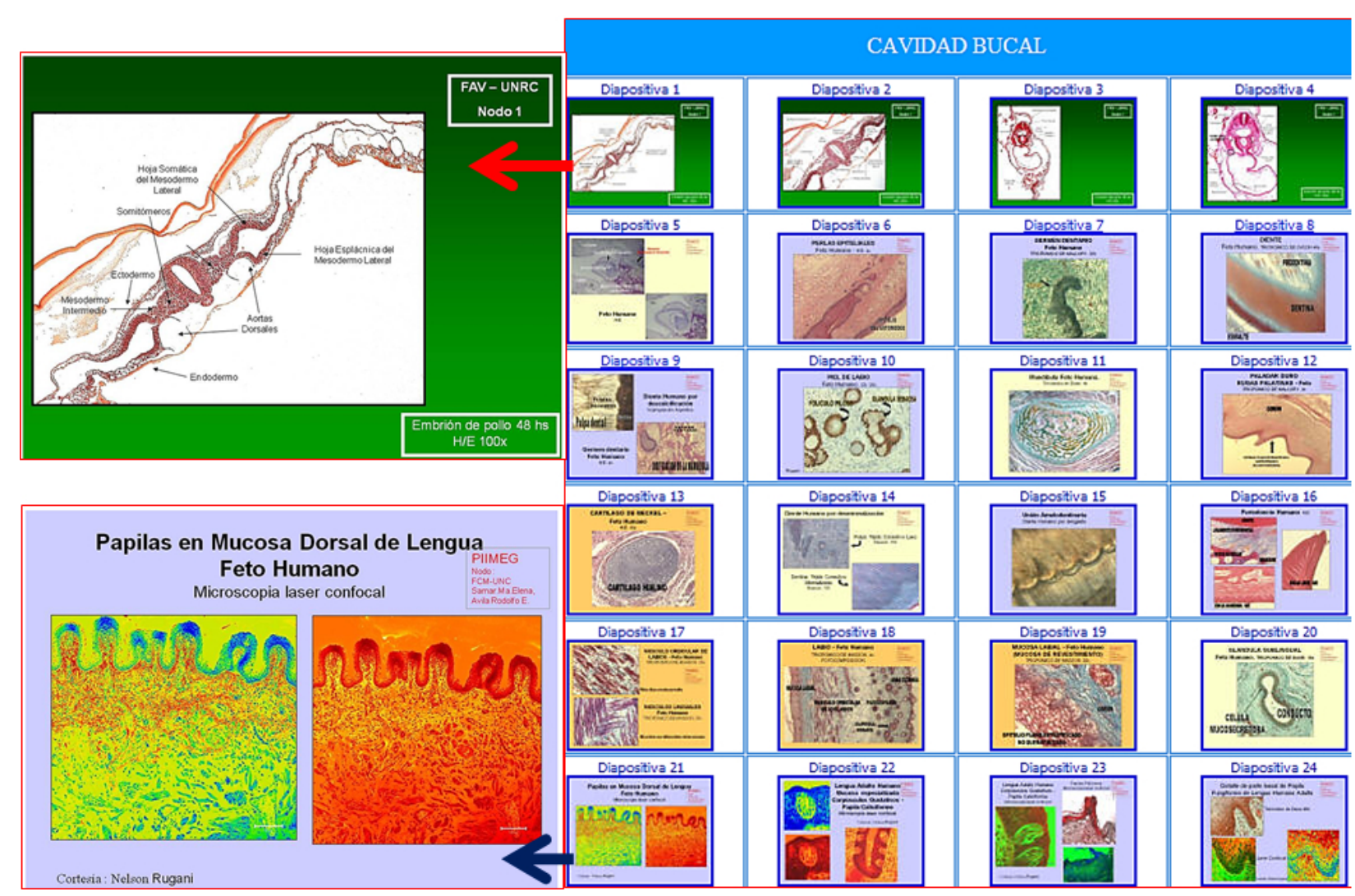

Figure 1.

Screenshot demonstrating 28 thumbnail images from the e-learning activity "oral cavity". Selecting a thumbnail opens a separate window in which the image is enlarged. Shown here are images of a chicken embryo and fetal tongue.

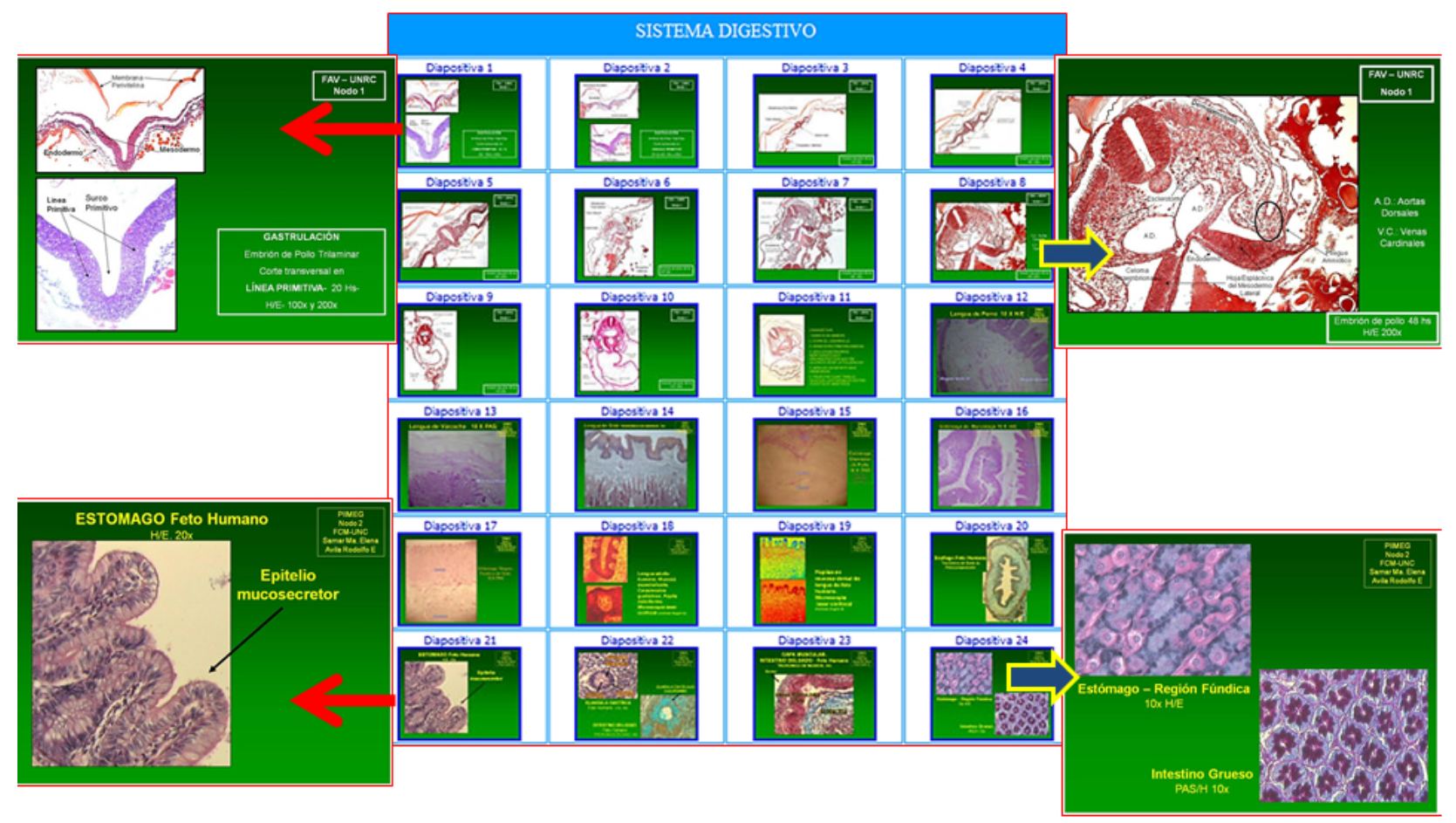

Figure 2.

Screenshot demonstrating 32 thumbnail images from the e-learning activity "digestive system”. Larger images are shown of the human stomach and intestine as well as a chicken embryo. 
play further information as above.

$44.4 \%$ of the cohort (total 300) who completed the cellular biology, histology and embryology module (medical undergraduates, National University of Cordoba) carried out the proposed e-learning activities. Of this subgroup, $84.9 \%$ sat the examination for that academic year. In terms of their performance, $99 \%$ passed the examination. The mean score obtained was $8.28 \pm 1.52$. Of the students who completed all of the e-learning, $40 \%$ achieved a score of 8 or higher, from a maximum of 10 points.

\section{Discussion}

Our results indicate that providing e-learning activities to students can facilitate the completion of learning objectives, through encouraging a personal commitment to continuous learning. This may then promote success in examinations and the achievement of higher scores.

The effectiveness of computer-based learning has been recognized and accepted since before the widespread use of the Internet (Ruiz, 2006). In the context of basic science education it is becoming increasingly used at both an undergraduate and postgraduate level due to several advantages (Sander, 2012; Avila, 2011; McCombs, 2007). The financial advantages of adopting e-learning of histology or "virtual microscopy" are clear, as many institutions are able to avoid the need of having to purchase and maintain conventional microscopes (Hamilton, 2012).

Levels of satisfaction amongst students are generally high. Hamilton et al. at Queen's University Belfast, found that virtual microscopy was preferred by $88 \%$ of undergraduate students, in a cohort who had previously received histology training with conventional microscopes (Hamilton, 2012). Possible reasons include the ability to access high quality, annotated images and the opportunity to discuss important features which can be demonstrated by the faculty.

Perhaps more importantly, this increased satisfaction is being translated into improved results on histology exams (Hamilton, 2012; Harris, 2001; Kumar, 2006; Gouldsborough, 2012). Furthermore, Gouldsborough et al. found that the benefits of e-learning modules in anatomy and histology extended beyond technical knowledge. Students subjectively felt that their nontechnical, team building and communication skills were improved, something which may in part be due to high levels of support on the website's message boards (Gouldsborough, 2012).

In our case we have been able to demonstrate the value of e-learning in delivering teaching to medical, dentistry and veterinary science students. We have found it important to use images obtained in biomedical laboratories in the development of educational tools. In addition, it is necessary to incorporate systematic audiovisual resources to develop effective and competitive educational material. For this reason, audiovisual archives have gained prominence in the production of digital educational materials (Avila, 2010; Avila, 2011; Shuter, 2011).

\section{Conclusion}

In summary, we have found that users have been able to integrate both theoretical and practical knowledge of cell biology, histology and embryology relevant to their digestive system learning objectives. In this way, online learning resources can play an important role in higher education by improving results and simultaneously overcoming temporal, financial and spatial constraints.

\section{Acknowledgements}

Grant of Secretariat for Planning and Institutional Relations, Secretariat for Science and Technology, Academic Secretariat of the Universidad Nacional de Río Cuarto. Argentina.

\section{REFERENCES}

Ávila, R. E., Alemany, L. A. I., Samar, M. A., Buzzetti, L. B., Juri, G., \& Juri, H. O. (2010). Extensions of a digital library of laboratory samples histopathology. International Journal of Morphology, 28, 875-878.

Ávila, R. E., Spinelli, O., Ferreira, A. S., Soñez, C., Samar, M. E., \& Ferreira Juniors, R. S. (2011). Online teaching collaboration in university education. Revista Brasileira de Educação Médica, 35, 429434. http://dx.doi.org/10.1590/S0100-55022011000300018

Ávila, R. E., \& Samar, M. E. (2011). Virtual histology project: ODONTOWEB. International Journal of Odontostomatology, 5, 1322.

Goldberg, H. R., \& Dintzis, R. (2007). The positive impact of teambased virtual microscopy on student learning in physiology and histology. Advances in Physiology Education, 31, 261-265. http://dx.doi.org/10.1152/advan.00125.2006

Gouldsborough, I., \& Choudhury, B. (2012). The use of electronic media to develop transferable skills in science students studying anatomy. Anatomical Sciences Education, 5, 125-131. http://dx.doi.org/10.1002/ase.1259

Hamilton, P. W., Wang, Y., \& McCullough, S. J. (2012). Virtual microscopy and digital pathology in training and education. APMIS, 120, 305-315. http://dx.doi.org/10.1111/j.1600-0463.2011.02869.x

Harris, T., Leaven, T., Heidger, P., Kreiter, C., Duncan, J., \& Dick, F. (2001). Comparison of a virtual microscope laboratory to a regular microscope laboratory for teaching histology. Anatomical Record (Part B: New Anatomist), 265, 10-14. http://dx.doi.org/10.1002/ar.1036

Kumar, R. K., Freeman, B., Velan, G. M., De Permentier, P. J. (2006). Integrating histology and histopathology teaching in practical classes using virtual slides. Anatomical Record (Part B: New Anatomist), 289B, 128-133. http://dx.doi.org/10.1002/ar.b.20105

McCombs, G. B., Ufnar, J. A., \& Shepherd, V. L. (2007). The virtual scientist: Connecting university scientists to the K-12 classroom through videoconferencing. Advances in Physiology Education, 31, 62-66. http://dx.doi.org/10.1152/advan.00006.2006

Ruiz, J. G., Mintzer, M. J., \& Leipzig, R. M. (2006). The impact of e-learning in medical education. Academic Medicine, 81, 207-212. http://dx.doi.org/10.1097/00001888-200603000-00002

Sander, B., \& Golas, M. M. (2012). HistoViewer: An interactive e-learning platform facilitating group and peer group learning. Anatomical Sciences Education, 5, 125-131.

Shuter, J., \& Stevenson, F. (2011). Conversion of an imaged-based lecture to a virtual microscopic tutorial; a practical approach including. Medical Science Educator, 21, 206-209.

Silva Lópes, V. W., \& Monteiro-Leal, L. (2003). Creating a histology-embryology free digital image database using high-end microscopy and computer techniques for on line biomedical education. Anatomical Record (Part B: New Anatomist), 273, 126-131. http://dx.doi.org/10.1002/ar.b.10021 